\title{
The Impact of Corporate Social Responsibility on Firm's Financial Performance in Malaysia
}

\author{
Dilashenyi Devi Selvarajah ${ }^{1}$, Uma Murthy ${ }^{1} \&$ Mathavi Massilamany ${ }^{1}$ \\ ${ }^{1}$ Global Leadership Research Unit, Faculty of Business, Accountancy and Management, SEGi University, \\ Malaysia \\ Correspondence: Dilashenyi Devi Selvarajah, Global Leadership Research Unit, Faculty of Business, \\ Accountancy and Management, SEGi University. Malaysia. E-mail: dilashenyiselvarajah@gmail.com
}

Received: November 29, 2017

Accepted: January 22, $2018 \quad$ Online Published: February 25, 2018

doi:10.5539/ijbm.v13n3p220

URL: https://doi.org/10.5539/ijbm.v13n3p220

\begin{abstract}
The present research aims at investigating the impact of CSR on firm's financial performance in Malaysia. Based on gaps in extant literature, the current study hypothesizes that four (4) independent variables comprising business risk, company reputation, employee engagement and stakeholder concern will exert statistically significant influences on the dependent variable, firm's financial performance. The research employs a quantitative research approach whereby a sample 153 respondents were collected using a stratified random sampling technique. Employing SPSS software, multiple linear regression analysis was carried out. The results of multiple regression revealed that out of the four (4) hypotheses of the research, three (3) were supported whilst one (1) was not. In particular, it was shown that business risk, company reputation and stakeholder concern exert statistically significant influences on firm's financial performance. However, there was no enough evidence to support the claim that employee engage can significantly influence firm's financial performance. Several implications from the research were further discussed and elaborated.
\end{abstract}

Keywords: business risk, company reputation, employee engagement, stakeholder concerns, firm's financial performance

\section{Introduction}

Corporate social responsibility (CSR) has been widely recognized by the society todays that all the organizations should hold a wider responsibility than short term profitability (Brammer \& Millington, 2004; Idowu \& Papasolomou, 2007). For example, one of the publisher named Business in the Community published Winning with Integrity in 2000 with the objectives of the way that the companies were measuring and reported the effects to the society (Business Impact, 2000). More and more companies has taken the initiatives to concern on CSR started with some small activities and programs and included such issues in their public communications such as annual reports, advertisements, thematic reports and etc. (Knox, 2005).

There is no doubt that CSR is a core of business ethics when objectivity and integrity. According to the book written by Bowen (1953), the author argued that firms needs to have acquaintance on business ethics in order to survive in this competitive industry and achieve perennial performance. According to Godfrey (2009), CSR activities are playing extremely imperative role in ethics because it provides a protection when negative issues happened in corporate. Besides that, CSR activities not only will prevent negative events from happening, they will also influence firm's financial performance such as sales growth and profitability. Sen et al (2006) also stated that CSR also would bring impact to bring impacts to employment and investment domain. The organizations with high CSR ratings could increase the firm's reputation and indirectly gain competitive advantages rooted in human capital as attractions of new employees and employee engagement are significant higher than the firms with lower CSR ratings (Carmeli 2005; Hunt et al. 1989; Turban and Greening 1997). Hence, implementation of CSR could bring impact to firms and also firm's financial performance.

This study is limited to only four variables as to keep the task manageable in a simple way. Previously, there are some studies have been carried out by researchers in examining the impact and significance of the concerns of CSR topic. For instance, Nguyen \& Nguyen (2015) has studied the impact of CSR on firm's business risk by influencing and changing the working attitude and performances of the employees. A research which written by Mirvis (2012) also discussed about the relevance of CSR for superior employees including the effect on employees' 
willpower, status and sense of meaning and purpose.

The importance of implementation of CSR is highly aware by the firm's in Western Countries, so do Malaysian firms. Changes were being proposed in order to generate a better environment and bring significant impact to the firm's financial performance as well. However, according to Association of Chartered Certified Accountant Malaysia (ACCA), stated that Malaysian firms still lack little evidence of awareness of CSR even though 43 percent of the companies reported some extent on social performance and 26 percent promised to implement CSR activities in the future. Besides that, ACCA also revealed multiple reporting weaknesses including firms being overly focused on philanthropic activities (ACCA, 2008).

The present research is guided by the following research questions (1) what is the effect of business risk on firm financial performance in Malaysia? (2) What is the effect of company reputation on firm financial performance in Malaysia? (3) What is the effect of employee engagement on firm financial performance in Malaysia? (4) What is the effect of stakeholders concern on firm financial performance in Malaysia?

To seek answers to these research questions, the present research will be organized into five (5) sections. Section one captures the introduction, section two discusses review of updated literature, section three (3) highlights the methodology employed in analyzing empirical data for this research, section four (4) discusses data collection and analysis whilst last but not least, section five (5) provides the conclusion and recommendations, as well as the contributions and limitations of the research.

\section{Literature Review}

\subsection{Defining Corporate Social Responsibility}

CSR is defined as to assist any organizations to maintain an equitable and workable balance among the directly claims of interested groups, in other words, a harmonious work life balance among shareholders, employees, customers and public at large (Frederick, 2006). Based on the research done by Yingjun Lu, Indra Abeysekera and Corrinne Cortese (2015), they said that CSR is a concept which is used to describe the social and environmental contributions and consequences of organizational activities (Yingjun Lu, 2015). A research done by Caroline D. Ditlev - Simonsen (2010), she also said that CSR is a concept which companies integrate social and environmental concerns in their business as well as interaction with their stakeholders on a voluntary basis (Ditlev-Simonsen, 2010). Furthermore, from the perspective of Luu Trong Tuan (2012), he said that CSR is focused on the commitment of the companies in order to contribute to sustainable development, stakeholders' interests and also societal enhancement (Tuan, 2012).

On the other hand, a research done by Yelena Smirnova (2012), she said that companies should take actions to protect and improve the environment and she also strongly emphasized that the environmental responsibility is part of the CSR (Smirnova, 2012). Next, Marty Stuebs and Li Sun (2015) defined CSR and said that CSR consists of five dimensions, which including vision, community relations, workplace, accountability and marketplace. For example, vision is the CSR conceptual development within the business operation. Community relations are the partnerships with different stakeholders such as suppliers, bankers, government, customers and so on. Workplace is the human rights and labor practices within the business operation. Meanwhile accountability is the transparency of financial report and marketplace includes the relationship between CSR and core business process (Sun, 2015).

According to Zulhamri Abdullah and Yuhanis Abdul Aziz, they defined CSR as the actions of a company that could benefit to the society (Aziz, 2013). Other than that, Stephen K. Nkundabanyanga and Alfred Okwee (2011) said that the CSR is a commitment by a company to behave ethically and contribute to economic development, where it can improve the quality of life of the workforce and also the local community as well as society (Okwee, 2011). Moreover, Mohammad Hallal and Hanin Abdallah (2010) also defined CSR as the commitment of a company to use its resources to benefit the local community and society in order to fulfill the public societal expectations said by researchers (Dima Jamali, 2010).

Based on a research done by Maimunah Ismail (2010), he said that CSR is a concept where companies consider the interest of society by taking responsibility for the impact of their activities on customers, suppliers, employees, shareholders, communities, and so on. This action shows that the companies have to comply with legislation and voluntarily take initiatives to improve the standard of living of its employees as well as the families of the employees (Ismail, 2010). Besides, CSR also defined as how companies used its resources to meet the expectations and needs of its stakeholders (Fontaine, 2013). Last but not least, from this research, CSR is an action that taken by companies in order to protect and improve the environment as well as local community 
and society. Therefore, CSR has become a hot topic in around the world, as it would be beneficial to local community and society as well as the company itself.

\subsection{Business Risk}

Nguyen and Nguyen (2015) have studied about the effect of CSR on firm risk and they reported CSR strengths relating to diversity and employee relations are also associated with higher risk. There are positive influence of both CSR strengths and concerns on a firm's risk is confirmed using aggregate CSR indicators. Gregory, Tharyan and Whittaker (2014) have studied the effect of CSR on firm value, effects on forecasted profitability, long-term growth and most importantly the possible risk (reducing) effect of CSR and their implication for financial measures of performances. As the result, they reported that implementation of CSR have higher expected growth rate with relatively low cost of equity and associated with lower risk factor loadings. These researchers got similar result from their research which reported that implementation of CSR activities could reduce the business risk. Without CSR activities, investors and employees might be more considerate on the

Hsu and Chen (2015) studied whether the firm's financial risk associated with corporate social responsibility and they demonstrated the importance of considering both positive and negative CSR performance. They proved that positive CSR ratings are associated with reduced financial risk while negative CSR performance scores lead to increased financial distress and of course, the investors respond to positive CSR ratings. Ayadi, Kusy, Pyo and Trabelsi (2015) have undergo research and investigate the association between CSR and managerial risk-taking and researchers reported that firms with strong CSR records are able to engage in higher risk-taking and high managerial risk-tolerance and necessary for the undertaking of risky yet profitable investment decision. Both group of researchers claimed that CSR could bring positive impact to the firm's financial performance by reducing the business risk.

Sun and Cui (2014) determined the relationship between CSR and default risk and the researchers reported CSR helps firms to reduce the risk of falling into default and the relationship of CSR and risk reduction is stronger on firms in high dynamism environments than in low dynamism environments. Furthermore, Kim, Li and Li (2014) also shows that CSR is negatively associated with future crash risk after controlling for other predictors of crash risk. The company that actively engage in CSR also refrain from bad news hoarding behavior, hence reducing crashing risk as well. The result proposed by these two groups of researchers gave a similar conclusion which CSR performance could reduce many types of business risk for the companies.

Jo and $\mathrm{Na}$ (2012) have studied about whether CSR could reduce firm risk and the researchers reported CSR engagement could help in that risk reductions and risk management efforts. Moreover, Cruz (2012) determined the supply-side disruption risks, social risks, and demand-side uncertainty within an integrated global supply chain and corporate social responsibility (CSR) modelling and analysis framework and the researcher came out with a conclusion that CSR activities can potentially be used to mitigate global supply chain risk. The researchers reported a negative association between CSR performance and firm's business and idiosyncratic risk. The researchers suggested that CSR performance is a type of investment which is similar to advertising and research and development (R\&D). Both researchers hold different concepts and point of view which gave a chance for reader to make comparison between the conclusions they had made.

According to Hoje and Maretno (2014), the researchers studied about the empirical association between analyst coverage and CSR by investigating their simultaneous and causal effects and its joint effects of CSR engagement and analyst coverage on firm risk. As the result, it stated that CSR engagement can use as a tool to reduce risk such as conflicts of interest between managers and non-investigating stakeholders. Besides that, Albuquerque, Durnev \& Koshinen (2013) studied the relationship between CSR and firm risk. The researchers reported that CSR policies affect firms' systematic risk and valuation based on the premise that CSR is an investment in customer loyalty.

\subsection{Company Reputation}

Another steam of literature posits that firms that have engagement in CSR activities could build reputation and bonding with the communities they are, increase the transparency and familiarity about the firm. It will also reduce the risk of litigation and reputation loss in the face of negative events. According to Taghian, D'Souza and Polosky (2015), these researchers studied the influences of CSR on reputations and business performances. They have identified association between CSR construct and corporate reputation and reported that there was a positive relationship between CSR and the reputation of the company. Research done by Gazzola (2014) also reveals a significant positive association between corporate social responsibility and corporate reputation. The more the socially responsible firms possess, the better the corporate reputations. Next research by Esen (2013) studied that CSR activities bring positive impact on corporate reputation and reported that CSR and company 
reputation have positive relationship between them. These three researches had written about there are relationships between company reputation and firm's financial performance which is the positive effect on it.

Besides, implementation of CSR could affect the company reputation, firm's financial performance, as well as the size of the firm which reported by $\mathrm{Lu}$, Abeysekera and Cortese (2015) in their research report. Arendt and Brettel (2010) examined the effects of CSR on corporate identity, image and as well as the firm performance in a multi-industry setting and reported that contingency models they used in research stated that the process of building corporate image and the percentage of successful are based on the company size, industry benchmarking and marketing budget. These researchers reported that CSR could bring impact to other factor of organization other than company reputations which may help companies to achieve their goals.

Abdullah and Aziz (2013) studied about the impact of CSR in company reputation in Malaysia. From the study of the researchers, they found out that CSR initiatives impact corporate reputation directly and effectively as well. However, Hanzaee and Sadeghian (2014) provides an evaluation of the impact of CSR as part of the social market according to current economic and conditions on corporate reputation in automotive industry. As a result, there is no significant correlation between execution of economic responsibility and corporate social and as well as the company reputation. There is a contrast between these two groups of researchers which both of them got different result from their researches. One of them are focus on the practical while another one is focus on the theoretical and practices respectively.

Besides, Othman, Darus and Arshad (2011) analyze that coercive isomorphism as imposed by regulatory authorities used to promote a company CSR reputation in developing countries. Regulatory efforts are significant mechanisms in promoting CSR reputation. Institutional owners regarding CSR reporting are able to enhance their CSR reputation while family-owned companies does not considered CSR to boost their company or business reputations. Sánchez, Sotorrío and Diez (2015) agreed that CSR practices bring significant positive effect on corporate reputation in turbulent environments as well as in the current financial crisis nowadays with the outcome from the research on Spanish Ibex35 companies. According to Maden, Arikan, Telci and Kantur (2012), these researchers ensured that CSR is not only act as precedent of the implementation, CSR has a strong positive effect on company reputation, indirectly company reputation has a strong positive effect on the behaviors of customers, employees, and investors. These three groups of researchers agreed that implementation of CSR in management's activities could bring positive effect for the corporate in turbulent environment, company reputations and most importantly CSR could help to affect stakeholders concern and the society.

\subsection{Employee Engagement}

On the other hand, Ferreira and Oliveira (2014) claimed that internal CSR plays an important role and they intended to understand the relationship between CSR and employee engagement. The result shows that there are no significant differences in level of engagement between employees exposed to external and internal CSR practices. However, employees exposed to internal CSR are more engaged as compared to those engaged externally. Impact of the internal CSR practices on organizational engagement was greater than job engagement which is agreed by Albdour and Altarawneh (2012). The results got from these two groups of researchers are comparable because they claimed the impact of CSR on employee engagement in different perspectives and views.

According to Gross (2011), the president of CR Strategies studied that CSR is an emerging and increasingly important driver in employee engagement which may bring significant impact to the organizations. He reported that with the implementation of CSR could promote the company reputation and indirectly heighten the percentage of employee engagement. Research which written by Mirvis (2012) stated that relevance of CSR for engaging employees, including its impact on their motivation, identity, and sense of meaning and purpose through three different ways which are transactional, relational and development approaches. These researchers agreed that CSR could bring impact to the employee engagement of the corporate in different sense, intention and ways.

Zafar, Nawaz Farooqui, Abdullah and Yousaf (2014) studied that employee retention strategies using CSR initiatives are one of the main factors that could affect employee retention and employee turnover in the companies. Besides that, the researchers also studied about how CSR affects employees in a positive way. They concluded that an effective CSR activities and model can bring positive result against employee engagement. Furthermore, Supanti, Butcher and Freline (2015) mentioned that CSR could enhance the relationship between employers and employees in five themes such as a relationship unifying process, having fun, feeling pride, developing skills and building teamwork, hence, it will bring positive effect on employees' engagement. Valentin, Valentin and Nafukho (2015) demonstrated that employee engagement has a wide range of benefits for all 
involved and focuses on key antecedents of engagement created through CSR initiatives and intrinsic motivating factors. These researches are reported and concluded with a similar result which implementation of CSR would bring positive impact to employees' engagement and also to the corporate.

Research from Smith (2012) was allocating attention and resources to corporate social responsibility may not be as advantageous as investing in the improvement of core human resource practices, when the goal is to improve employee engagement. Sun and Yu (2015) examined the conjectures, which prior literature suggests which employees work more productively in socially responsible companies and they are willing to work over time.

\subsection{Stakeholder Concerns}

Hanzaee and Sadeghian (2014) discussed about the implementation of CSR activities with the consideration of major stakeholders by localized model of the most basic and responsibilities to start a new perspective in order to increase the performance of the company. The next research written by Mishra and Suar (2010), the researchers examine the strategy towards primary stakeholders and their significant influence CSR towards the corresponding stakeholders. CSR brings salience influences on employees and researchers reported that implementation of CSR affects all stakeholders group and hence, indirectly affect the companies. Hanzaee and Sadeghian (2014) stated that there is no proportional correlation between economic responsibility and corporate social and company reputation. However, Mishara and Suar (2010) reported that CSR is the most favorable strategy implemented towards stakeholders increases the corresponding corporate social responsibility towards them.

Gond, El-Akremi, Igalens and Swaen (2010) studied about the influence of CSR on employees and they concluded that implementation of CSR in the organization would trigger changes on employees' working attitudes and behavior. Besides, Ali, Rehman, Ali, Yousaf \& Zia (2010) reported that the multifaceted influence of CSR on employee's organizational commitment and organizational performance. Both researchers agreed that with the implementation of CSR could change the employees' working attitude and performance to become better and indirectly raise the organizational performance.

According to Taghian, D'Souza and Polosky (2015), these researchers studied the influences of CSR on stakeholders, reputations and business performances. They have identified that employees and the public are perceived to be influential stakeholders groups in CSR decision making report and reported that there was a significant relationship between CSR and stakeholders. Fadun (2014) indicated that CSR is concerned with treating stakeholder ethically and business should protect wide range of stakeholders' interest and there is a significant relationship between CSR and stakeholders' expectations. From this discussion, it can be concluded that both researchers agreed that implementation of CSR could bring significant influence to the employees and the CSR activities must be protect stakeholders' interest in order to achieve the purpose of having CSR in the management of the organizations.

Bauma and Skitka (2012) have studied that CSR is representing a special opportunity to influence employees' general impression of their company and also identify how CSR would affect employees' relationship with their company. They reported that there is a relationship between CSR, employees and companies. Li, Lin and Yang (2016) reported that their research tends to examine the association between stakeholders and CSR documented in developed countries exists in China. As the result, their research came out with a conclusion that central government, suppliers' concentration and foreign investors are positively association with CSR whereas concentration of shareholders and customers are negatively associated with CSR in China. Both researchers came out with similar results that CSR could enhance the relationship between stakeholder and companies. However, Li, Lin and Yang (2016) came out with more specific and detail result.

McDonald \& Lai (2015) tended to determine whether Taiwanese retail banking customers' preferences in CSR initiatives that favor themselves or other stakeholder groups such as community and environment and whether these initiatives bring impact to customers' attitude and behavioral intentions. There are a lot of arguments in this research as to prove that stakeholders do have significant approach to CSR and the significant result only shown the differences between customer-centric and environmental initiatives. Based on Spitzeck and Hansen (2010) research, they were focusing on the non-managerial stakeholders' perceptions of the barriers to corporate social and environmental responsibility practices in developing countries context. However, they found out that lack of awareness among various group of stakeholders regarding the influential role of CSR. Both researchers have contrary results from their researches which provide a comparison for readers to understand deeply about impact of CSR on stakeholder concerns in different aspect and indirectly to the firm's financial performance as well as the working environment of the companies as well. 


\subsection{Theories}

There are some other theories which can used to understand or explain motivations behind social and environmental disclosures, for example classical theory, stakeholder theory, social demander's theory, and social activist theories. The aim of such activities is to make sure that organizational social responsibility concerns are treated in the same routine manner in which legal, financial and marketing concerns are addressed (Padgett, 2011).

The classical theory is the oldest of the four theories, and it is grounded in classical economic theory. This theory has two versions. In the first, business executives are said to be primarily responsible to the shareholders of the corporation, and their primary goal is to promote efficiency and to secure effective economic performance. In the second version, managers are said to be responsible to respond to the shareholders' demands. These views are often thought to coincide with each other, because it is usually assumed that the main demand of shareholders is to maximize economic performance. In Addition, both versions agree that managers are to perform their corporate functions according to the laws and thus, to avoid such things as fraud and deception (Pedro Luiz Cortes, 2014).

The stakeholder theory assumes that corporate executives are responsible to stockholders in the other hand it also insists that there are other groups directly affected by the conduct of the firm. Employees, consumers, creditors, suppliers, and legal subsystems are constituents who have a stake in the corporation and who might affect, in one way or another, corporate decision making (Oyvind Ihlen, 2014). Therefore, corporate executives have a direct responsibility to promote the interests of these groups (satisfied stakeholders, reduced likelihood of stakeholder action and even financial returns). The term refers to the many interest groups who can affect, or be affected by, the organization's activities such as investor, employees, customers, suppliers, government, pressure groups and the wider society.

Social demandingness theorists argue that corporations have a responsibility to protect and to promote certain interests of the general public. They agree with the stakeholder theorists that the interests of stakeholder group are important. But they believe that these interests do not override non-stakeholders' interests or demands for such things as safety, health, freedom and prosperity (Wang, 2011). As with the stakeholder theory, this one repudiates the notion that there is some balanced or sensible list of tangible responsibilities that corporate executives always have toward society (Delgedo, 2011). The social activist theory is distinctively the most socially and morally demanding of the four theories. While agreeing with the stakeholder and social demandingness theories that executives have responsibilities toward stakeholder groups and the general public, social activist theorists argue that corporate manager should sometimes strive to undertake projects that advance the interest of the public, even when these undertakings are neither expected nor demanded by them. Social activist theorists contend that such project should, for the most part, be in the area of corporate know-how, but they sometimes urge that executives deliberately take on social projects for which they have no special training or expertise (Rahman, 2014).

\subsection{Proposed Framework}

The relationship between four impact of CSR and firm's financial performance are shown below:

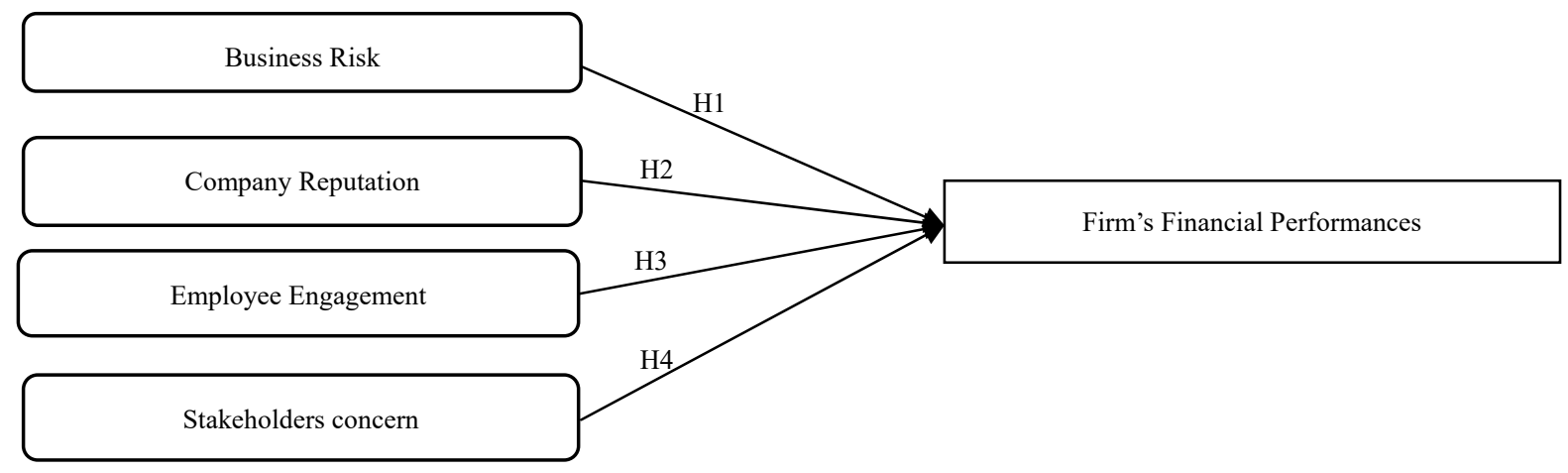

Figure 1. Research hypothesis

Based on the previous studies regarding impact of CSR on firm's financial performance, the following are the 
hypothesis proposed in this research report:-

H1: There exist a direct significant relationship between business risk and firm's financial performances in Malaysia.

H2: There exist a direct significant relationship between company's reputation and firm's financial performances in Malaysia.

H3: There exist a direct significant relationship between employee engagement and firm's financial performance in Malaysia.

H4: There exist a direct significant relationship between stakeholders concern and firm's financial performance in Malaysia.

\section{Research Methodology}

\subsection{Measurement and Collection of Data}

A quantitative research approach is employed in this research following the positivist assumption with a realist ontology and objectivist epistemology. Data was collected using a probabilistic sampling method, particularly a stratified random sampling technique. The topics covered in this chapter include Descriptive analysis, Normality test, multiple regression analysis and Scale measurement.

The adapted survey questionnaire employed in this study is divided into two sections; demography and scales of the four (5) underlying factors of the research instrument, capturing four (4) independent variables and 1 dependent variables. A 5-point Likert scale was used showing (1)"strongly disagree", (2) "disagree", (3) "slightly agree", (4) "agree", (5) "strongly agree This test must be determined before a survey can be employed for research purpose to ensure validity and reliability (Cronbach, 1951). Hence, the cronbach alphas of all 25 items in the scale shows 0.961 , above and over 0.7 cut off threshold (Sekaran \& Bougie,2010) which suggest that the reliability of the scales for measuring business risk, company reputation, employee engagement and stakeholders concern is reliable and can be used for further analysis.

Table 1. Adapted Scales from Previous Studies.

\begin{tabular}{ll}
\hline Variable & Source \\
\hline 1) Business Risk & (Fadun, S. O. (2014) \\
2) Company's Reputation & (Ofori, D.F., Nyuur R.B. \& S-Darko, M.D., (2014) \\
3) Employee Engagement & (Barnes, A. J. (2011) \\
4) Stakeholder concern & (Fadun, S. O. (2014). \\
\hline
\end{tabular}

\subsection{Demography of Respondents}

Table 2. Gender, Age, Married Status and Education Level

\begin{tabular}{|c|c|c|c|}
\hline Types & Categories & Frequency & Percent \\
\hline \multirow[t]{2}{*}{ Gender } & Male & 86 & 56.2 \\
\hline & Female & 67 & 43.8 \\
\hline \multirow[t]{5}{*}{ Age } & 18 years old and below & 24 & 15.7 \\
\hline & 23-27 years old & 70 & 45.8 \\
\hline & 38-32 years old & 33 & 21.6 \\
\hline & $33-37$ years old & 17 & 11.1 \\
\hline & 38 years old and above & 9 & 5.8 \\
\hline \multirow[t]{2}{*}{ Marital Status } & Single & 69 & 34.5 \\
\hline & Married & 131 & 65.5 \\
\hline \multirow[t]{4}{*}{ Education Level } & Secondary & 9 & 5.9 \\
\hline & STPM/A-LEVEL/ Foundation/UEC & 16 & 10.5 \\
\hline & Undergraduate & 89 & 58.2 \\
\hline & Postgraduate & 39 & 25.4 \\
\hline
\end{tabular}


Table 3. Correlation analysis

\begin{tabular}{|c|c|c|c|c|c|c|c|}
\hline & & & $\begin{array}{l}\text { Financial } \\
\text { Performance }\end{array}$ & $\begin{array}{l}\text { Business } \\
\text { Risk }\end{array}$ & $\begin{array}{l}\text { Company } \\
\text { Reputation }\end{array}$ & $\begin{array}{l}\text { Employee } \\
\text { Engagement }\end{array}$ & $\begin{array}{l}\text { Stakeholder } \\
\text { Concerns }\end{array}$ \\
\hline $\begin{array}{l}\text { Financial } \\
\text { Correlation }\end{array}$ & Performance & Pearson & 1 & $.809 * *$ & $.759 * *$ & $.631^{* *}$ & $.448^{* *}$ \\
\hline $\begin{array}{l}\text { Business Ris } \\
\text { Person Corre }\end{array}$ & $\begin{array}{l}\text { sk } \\
\text { elation }\end{array}$ & & & 1 & $.792 * *$ & $.655^{* *}$ & $.544 * *$ \\
\hline $\begin{array}{l}\text { Company } \\
\text { Correlation }\end{array}$ & Reputation & Pearson & & & 1 & $.767 * *$ & $.618 * *$ \\
\hline $\begin{array}{l}\text { Employee } \\
\text { Correlation }\end{array}$ & Engagement & Pearson & & & & 1 & $.714^{* *}$ \\
\hline $\begin{array}{l}\text { Stakeholder } \\
\text { Correlation }\end{array}$ & Concerns & Pearson & & & & & 1 \\
\hline
\end{tabular}

** Correlation is significant at the 0.01 level (2-tailed).

Based on Table 3 as shown above, the correlation of each of the independent variable which are including business risk, company reputation, employee engagement and stakeholders' concern is significant at the 0.01 level, two tailed towards the dependent variable, firm's financial performance. The Pearson correlation coefficients assess the degree of linear relationship between the two variables (Hair, Anderson, Tatham \& Black, 1998). As the result shown in the table, all the variables are correlated as each of the variables are between ranges of 0.4 to 0.9 , which is between the ideal ranges of -1 to +1 . Thus, there is no other issue in this project and further no variables need to be excluded as it has no multicollinearity problem.

According to Table 3, the significant value of business risk, company reputation, employees engagement and stakeholders' concern against firm's financial performance are equally 0.000 which are smaller than 0.05 (p-value $\leq 0.05$ ). Hence, there is a relationship between business risk and firm's financial performance. Besides, other independent variables which are including company reputation, employee engagement and stakeholders' concern also have relationship with the dependent variables, firm's financial performance as well.

\subsection{Multiple Regression Analysis}

Model Summary ${ }^{\mathrm{b}}$

\begin{tabular}{llllll}
\hline Model & R & R Square & Adjusted R Square & Std. Error of the Estimate & Durbin-Watson \\
\hline 1 & $.838^{\mathrm{a}}$ & .702 & .694 & .45976 & 1.747 \\
\hline
\end{tabular}

a. Predictors: (Constant), Stakeholder_Concern, Business_Risk, Employee_Engagement, Company_Reputation

b. Dependent Variable: Financial_Performance.

\subsection{Model Summary}

Durbin Watson from above table include the number of test in order to detect the errors from a statistical analysis and ' $R$ ' is used to measure the relationship between the observed value and predicted value of dependent variable while ' $\mathrm{R}$ square' processes the amounts of variance in dependent variable that is accounted by independent variables (Cohen, Manion, \& Morrison, 2013). R-square in this research is 0.702 which means that $70.2 \%$ of total variance in the dependent variable (firm's financial performance) is explained by the total independent variables (business risk, company reputation, employee engagement and stakeholders' concern). Another $28.8 \%$ might be accounted by other variables which are not included in this research. On the other hand, Durbin-Watson in this research is 1.747 , the value is between the cut-off threshold between 1 to 3 and it indicates that there is no autocorrelation among the residuals (homoscedasticity). 
Table 4. ANOVAa

\begin{tabular}{llllll}
\hline Model & & Sum of Squares & Df & Mean Square & F \\
\hline 1 & Regression & 73.572 & 4 & 18.393 & 87.014 \\
& Residual & 31.284 & 148 & .211 & $.000^{\mathrm{b}}$ \\
& Total & 104.855 & 152 & & \\
\hline
\end{tabular}

a. Dependent Variable: Financial_Performance.

b. Predictors: (Constant), Stakeholder_Concern, Business_Risk, Employee_Engagement, Company_Reputation.

According to Table 4, it shown the output of analysis of variance (ANOVA). ANOVA table is referred to the significant value of the data analysis and it is important as the significant value equal or less than 0.05 ( $p$-value $\leq 0.05)$ which carries the meaning of the model is fit to use. The significant value of the regression of this research is 0.000 ( $p$-value $=0.000$ ). It showed that the IVs (business risk, company reputation, employee engagement and stakeholders' concern) are significantly affecting the DV (firm's financial performance). Therefore, the below table 4 , the coefficient table is given in order to check significant level of variables individually.

Table 5. Coefficients ${ }^{\mathrm{a}}$

\begin{tabular}{|c|c|c|c|c|c|c|c|c|}
\hline \multirow{3}{*}{\multicolumn{2}{|c|}{ Model }} & \multicolumn{6}{|c|}{ Standardized } & \\
\hline & & \multicolumn{4}{|c|}{ Unstandardized Coefficients Coefficients } & \multirow{3}{*}{$\frac{\text { Sig. }}{.002}$} & \multicolumn{2}{|c|}{ Collinearity Statistics } \\
\hline & & $\mathrm{B}$ & Std. Error & Beta & $\mathrm{t}$ & & Tolerance & VIF \\
\hline \multirow[t]{5}{*}{1} & (Constant) & .451 & .146 & & 3.096 & & & \\
\hline & Business_Risk & .587 & .078 & .561 & 7.555 & .000 & .365 & 2.736 \\
\hline & Company_Reputation & .267 & .079 & .296 & 3.376 & .001 & .262 & 3.812 \\
\hline & Employee_Engagement & .122 & .073 & .133 & 1.669 & .097 & .317 & 3.155 \\
\hline & Stakeholder_Concern & -.140 & .067 & -.135 & -2.082 & .039 & .476 & 2.100 \\
\hline
\end{tabular}

a. Dependent Variable: Financial_Performance.

Based on Table 5 above, the following linear equation is generated:

Firm's Financial Performance $=\mathbf{0 . 4 5 1}+\mathbf{0 . 5 8 7}($ Business Risk $)+0.267$ (Company Reputation) +0.122 (Employee Engagement) + (-0.140) (Stakeholders' Concern)

The 'Sig' indicates the importance of the variables affecting the DV in the research and for the significance value whereby $p$-value is less than 0.05 . According the result shown in table 10 , there is a variable which are not significant as its p-value is more than 0.05. 'Employee Engagement' with p-value of 0.097 while the other three variables are within the ideal coefficient which is less than 0.05 . The hypotheses of 'business risk' carried the p-value of 0.002 , 'company reputation' with p-value of 0.000 and 'stakeholders' concern' with the p-value of 0.039 . Hence, the result implies that the firm's financial performance is affected by business risk, company reputation, as well as the stakeholders' concern. However, there is no specific evidence to claim that firm's financial performance would be affected by 'employee engagement'. Besides that, VIF used to check the collinearity of the variables with the ideal ratio of VIF less than 10. From the above table 5, the VIF of all the variables are less than 10 which means there is no multicollinearity problem in the research. 


\section{Hypotheses Results}

\begin{tabular}{llll}
\hline & Hypotheses Statement & Sig. & Result \\
\hline$H_{1} 1$ & $\begin{array}{l}\text { There exist a direct significant relationship between business } \\
\text { risk and firm's financial performances. }\end{array}$ & 0.000 & Supported \\
$H_{2} 2$ & $\begin{array}{l}\text { There exist a direct significant relationship between company's } \\
\text { reputation and firm's financial performances. }\end{array}$ & 0.001 & Supported \\
$H_{3} 3$ & $\begin{array}{l}\text { There exist a direct significant relationship between employee } \\
\text { engagement and firm's financial performance. }\end{array}$ & 0.097 & Rejected \\
$H_{4} 4$ & $\begin{array}{l}\text { There exist a direct significant relationship between } \\
\text { stakeholders concern and firm's financial performance. }\end{array}$ & 0.039 & Supported \\
\hline
\end{tabular}

\section{Discussion of Findings}

In this research, there are 153 respondents have filled in the questionnaire. Most of the respondents are from the age range of 23-27 years old, married status is married, education level under undergraduate. Under the pilot study test, the reliability test result is 0.961 which means it shows the questionnaire is reliable and ideal.

\subsection{Result of the Correlation and Multiple Regression Analysis}

These results are came from 153 respondents and analyzed by SPSS. In the correlation test, there has pearson correlation of firm's financial performance. Firm's financial performance has a weak relationship with the business risk, company reputation, and employee engagement, however it has a moderate relationship between the stakeholders' concern. In the multiple regression analysis, there have model summary, AVOVA and coefficient table. Durbin- Watson is 1.747 in the model summary; it means the value is considered as an ideal value. $\mathrm{R}$ square in the model summary is $70.2 \%$; it means $70.2 \%$ of the independent variables will affect the dependent variable. The significant value for ANOVA is 0.000 , so it is consider ideal value because the result should not be more than 0.05, once it's beyond the amount, it is not accepted. Business risk, company's reputation and stakeholder's concern will be accepted because the results are less than 0.05 . Therefore, the null hypothesis of these variables is accepted.

\subsection{Implication of the Study}

This research was studied about the corporate social responsibility (CSR) which is one of the hot topic discussed and issue occurred in the society. Approximately all of the employees were requesting to get work life balance in their working life in order to balance up their works and family. However, from the management or organizations' point of view, they would rather maximize the performance of the organizations, in terms of revenue than the benefit of the employees. Undoubtedly, their opinions have always been a common issue in every of the organizations due to the differences. This study can be as the guidance for the public as the result of the analysis is based on the data collections from the companies in Klang Valley. The survey was done by the staffs, managers or even directors of the companies which the result shown in general point of view without any biasness.

\subsection{Recommendation for Future Research}

For recommendation, there is one hypothesis of independent variables which is employee engagement is not supported in the multiple regression analysis. It needs to be further analysed with sufficient time and more detailed information by the future analysis. There might be the structures and the questionnaires were unsuitable to use for the variable, hence, it is recommended to have efficient time and more specific information on analysing the data on SPSS software. However, the standardization of structures and questionnaires should be applied in order to improve the result and generate more accurate analysis. Even though the research study has limitation of time to complete the data analysis, it has benefited the researcher with the knowledge and ideas on doing research projects more effectively and efficiently. Besides that, this research project can be used as a guidance for future researchers with the brief idea of 'the impact of corporate social responsibility on firm's financial performance'.

\section{Conclusion}

This study was directed to have better idea about CSR affected the firm's financial performance by justifying the impacts of CSR on business risk, company reputation, employee's engagement and stakeholders concern. Hence, there were several of research objectives, research questions and hypotheses was developed at the beginning and analyzed after data collection. The result from Pearson correlation test, multiple regression analysis and reliability 
analysis test showed the significant result on all variables. However, there is one of the hypotheses is not supported while the other three hypotheses are supported. The hypotheses of business risk, company reputations and stakeholders concern are maintained in the study which indicates that CSR could bring impact to the company business risk, affecting the company reputations in the market as well as the stakeholders would be paying more attention in the effect of implications of CSR. As the results, for those organizations that implied CSR could bring positive results on the business risk, company reputations as well as the stakeholders concern towards the firms or organizations. Hence, implication of CSR might not be the only reason that fully affect the employee engagement towards the companies.

\section{References}

Abdullah, Z., \& Aziz, Y. A. (2013). Institutionalizing corporate social responsibility: Effects on corporate reputation, culture, and legitimacy in Malaysia. Social Responsibility Journal, 9(3), 344-361, https://doi.org/10.1108/SRJ-05-2011-0110

Ali, I., Rehman, K. U., Ali, S. I., Yousaf, J., \& Zia, M. (2010). Corporate Social Responsibility Influences, Employee Commitment \& Organizational Performance. African Journal of Business Management, 4(12), 2796-2801.

Arendt, S., \& Brettel, M. (2010). Understanding the influence of corporate social responsibility on corporate identity, image, and firm performance. Management Decision, 48(10), 1469-1492. https://doi.org/10.1108/00251741011090289

Ayadi, M. A., Kusy, M. I., Pyo, M. Y., \& Trabelsi, S. (2015). Corporate Social Responsibility, Corporate Governance, and Managerial Risk-Taking. Journal of Theoretical Accounting Research, 50-113.

Aziz, Z. A. (2013). Institutionalizing corporate social responsibility: effects on corporate reputation, culture, and legitimacy in Malaysia. Social Responsibility Journal, 9(3), 344-361. https://doi.org/10.1108/SRJ-05-2011-0110

Bauma, C. W., \& Skitka, L. J. (2012). Corporate social responsibility as a source of employee satisfaction. Research in Organization Behavior, 54, 1-24. https://doi.org/10.1016/j.riob.2012.11.002

Bowen, H. R. (1953). Social Responsibilities of the Businessman. New York: Harper \& Row.

Brammer, S., \& Millington, A. (2004). Stakeholder pressure, organizational size, and the allocation of departmental responsibility for the management of corporate charitable giving. Business \& Society, 43(3), 268295. https://doi.org/10.1177/0007650304267536

Carmeli, A. (2005). Perceived external prestige, affective commitment, and citizenship behaviors. Organization Studies, 26(3), 443-464.

Cruz, J. M. (2013). Mitigating global supply chain risks through corporate social responsibility. International Journal of Production Research, 51(13), 3995-4010. https://dx.doi.org/10.1080/00207543.2012.762134

Ditlev-Simonsen, C. D. (2010). From corporate social responsibility awareness to action? Social Responsibility Journal, 6(3), 452-468. https://doi.org/10.1108/17471111011064807

Esen, E. (2013). The Influence of Corporate Social Responsibility (CSR) Activities on Building Corporate Reputation. Advances in Sustainability and Environmental Justice, 11, 133-150, https://doi.org/10.1108/S2051-5030(2013)0000011010

Frederick, W. (2006). Corporation, be good! The story of corporate social responsibility. Indianapolis: Dog Ear Publishing.

Godfrey, P. C., Merrill, C. B., \& Hansen J. M. (2009). The relationship between corporate social responsibility and shareholder value: An empirical test of the risk management hypothesis. Strategic Management Journal, 30(4), 425-445. https://doi.org/10.1002/smj.750/full

Gond, J. P., El-Akremi, A., Igalens, J., \& Swaen, V. (2010). Corporate Social Responsibility Influence on Employees. Research Paper Series International Centre for Corporate Social Responsibility, 54.

Hanzaee, K. H., \& Sadeghian, M. (2014). The impact of corporate social responsibility on customer satisfaction and corporate reputation in automotive industry: Evidence from Iran. Journal of Islamic Marketing, 5(1), 125-143. https://doi.org/10.1108/JIMA-05-2013-0033

Hoje, J., \& Maretno, H. (2014). Analyst coverage, corporate social responsibility, and firm risk. Business Ethics: A European Review, 23(3), 272 - 292. https://doi.org/10.1111/beer.12051 
Hsu, F. J., \& Chen, Y. C. (2015). Is a firm's financial risk associated with corporate social responsibility? Management Decision, 53(9). https://doi.org/10.1108/MD-02-2015-0047

Idowu, S. O., \& Papasolomou, I. (2007). Are the corporate social responsibility matters based on good intentions or false presences? An empirical study of the motivations behind the issuing of CSR reports by UK companies. Corporate Governance: The International Journal of Effective Board Performance, 7(2), 136-147. https://doi.org/10.1108/14720700710739787

Jo, H., \& Na, H. (2012). Does CSR Reduce Firm Risk? Evidence from Controversial Industry Sector. Journal of Business Ethics, 110(4), pp. 441-456. https://doi.org/10.1007/s10551-012-1492-2\

Kim, Y. T., Li, H. D., \& Li, S. Q. (2014). Corporate social responsibility and stock price crash risk. Journal of Banking \& Finance, 43, 1-13.

Knox, S., Maklan, S., \& French, P. (2005). Corporate social responsibility: exploring stakeholder relationships and program reporting across leading FTSE companies. Journal of Business Ethics, 61(1), 7-28.

Li, D. W., Lin, H., \& Yang, Y. W. (2016). Does the stakeholders-corporate social responsibility (CSR) relationship exist in emerging countries? Evidence from China. Social Responsibility Journal, 12(1), 147-166, https://doi.org/10.1108/SRJ-01-2015-0018

Lu, I. A. (2015). Corporate social responsibility reporting quality, board characteristics and corporate social reputation: Evidence from China. Pacific Accounting Review, 27(1), 95-118. https://doi.org/10.1108/PAR-10-2012-0053

Lu, Y. J., Abeysekera, I., \& Cortese, C. (2015). Corporate social responsibility reporting quality, board characteristic and corporate social reputation: Evidence from China. Pacific Accounting Review, 27(1), 95-118. https://doi.org/10.1108/PAR-10-2012-0053

Maden, C., Arikan, E., Telci, E. E., \& Kantur, D. (2012). Linking corporate social responsibility to corporate reputation: A study on understanding behavioral consequences. Procedia-Social Behavioral Sciences, 58, 655-664. https://doi.org/10/1016/j.sbspro.2012.09.1043

McDonald, L. M., \& Lai, C. H. (2011). Impact of corporate social responsibility initiatives on Taiwanese banking customers. International Journal of Bank Marketing, 29(1), 50-63. https://doi.org/10.1108/02652321111101374

Mirvis, P. (2012). Employee Engagement and CSR: Transactional, Relational, and Development Approaches. California Management Review, 54(4), 97-117.

Moir, L. (2001). What do we mean by corporate social responsibility? Corporate Governance: The International Journal of Business in Society, 1(2), 16-22. https://doi.org/10.1108/EUM0000000005486

Nguyen, P., \& Nguyen, A. (2015). The Effect of Corporate Social Responsibility on Firm Risk. Social Responsibility Journal, 11(2), pp. 324-339. https://doi.org/10.1108/SRJ-08-2013-0093

Sánchez, J. L. F., Sotorrío, L. L., \& Diez, E. B. (2015). The relationship between corporate social responsibility and corporate reputation in a turbulent environment: Spanish evidence of the Ibex35 firms. Corporate Governance, 15(4), 563-575.

Sen, S., Bhattacharya, C. B., \& Korschun, D. (2006). The Role of Corporate Social Responsibility in Strengthening Multiple Stakeholder Relationships: A Field Experiment. Journal of the Academy of Marketing Science, 34(2), 158-66. https://doi.org/10.1177/0092070305284978

Smirnova, Y. (2012). Perceptions of corporate social responsibility in Kazakhstan. Social Responsibility Journal, 8(3), 404-417. https://doi.org/10.1108/17471111211247974

Spitzeck, H., \& Hansen, E. G. (2010). Stakeholder governance: how stakeholders influence corporate decision making. Corporate Governance: The International Journal of Business in Society, 10(4), 378-391. http://dx.doi.org/10.1108/14720701011069623

Sun, L., \& Yu, T. R. (2015). The impact of corporate social responsibility on employee performance and cost. Review of Accounting and Finance, 14(3), 262-284. https://doi.org/10.1108/RAF-03-2014-0025

Sun, M. S. (2015). Corporate governance and social responsibility. International Journal of Law and Management, 57(1), 38-52. https://doi.org/10.1108/IJLMA-04-2014-0034

Sun, W. B., \& Cui, K. X. (2014). Linking corporate social responsibility to firm default risk. European Management Journal, 32(2), 275-287. 
Taghian, M., D'Souza, C., \& Polonsky, M. (2015). A Stakeholder Approach to Corporate Social Responsibility, Reputation and Business Performance. Social Responsibility Journal, 11(2), 340-363. https://doi.org/10.1108/SHJ-06-2012-0068

Tuan, L. T. (2012). Corporate social responsibility, ethics, and corporate governance. Social Responsibility Journal, 8(4), 547-560.

Turban, D. B., \& Greening, D. W. (1997). Corporate social performance and organizational attractiveness to prospective employees. The Academy of Management Journal, 40(3), 658-672.

Yu, L. S. (2015). The impact of corporate social responsibility on employee performance and cost. Review of Accounting and Finance, 14(3), 262-284. https://doi.org/10.1108/RAF-03-2014-0025

Zafar, F., Nawarz, A., Farooqui, A., Abdullah, M., \& Yousaf, I. (2014). Employees' Retention through Corporate Social Responsibility in Large Scale Organization. International Journal of Business and Behavioral Sciences, 4(1), 1-30.

Zulhamri Abdullah, Y. A. (2013). Institutionalizing corporate social responsibility: effects on corporate reputation, culture, and legitimacy in Malaysia. Social Responsibility Journal, 9(3), 344-361, https://doi.org/10.1108/SRJ-05-2011-0110

\section{Copyrights}

Copyright for this article is retained by the author(s), with first publication rights granted to the journal.

This is an open-access article distributed under the terms and conditions of the Creative Commons Attribution license (http://creativecommons.org/licenses/by/4.0/). 